\title{
Arbuscular Mycorrhizal Fungal Spore Density and Root Colonization in Weeds of Carrot field at Charsadda, Pakistan
}

\author{
Tabassum Yaseen ${ }^{1 *}$, Shehzad Ahmad ${ }^{1}$, Khushnood Ur Rehman ${ }^{2}$, Fayaz Asad $^{1}$, Abdul Waheed ${ }^{1}, \operatorname{Rani}_{\text {Gul }}{ }^{3}$, \\ Hussain Gulab ${ }^{4}$ and Naveed Akhtar ${ }^{2}$
}

${ }^{1}$ Department of Botany, Bacha Khan University, Charsadda, Khyber Pakhtunkbwa, Pakistan; ${ }^{2}$ Department of Botany, Islamia University, Peshawar, Khyber Pakbtunkbwa, Pakistan; ${ }^{3}$ Department of Agriculture Bacha Khan University, Charsadda, Khyber Pakbtunkbwa, Pakistan; ${ }^{4}$ Department of Chemistry, Bacha Khan University, Charsadda, Khyber Pakbtunkbwa, Pakistan.

\begin{abstract}
Arbuscular mycorrhgizal fungi that forming symbiotic associations with plants through roots. It forms the multi colonization systems with the roots and provide benefits to the host plants. The present study was conducted to evaluate the occurrence and distributions of Arbuscular mycorrhizal fungi in the rhizospheric soil of major weeds of District Charsadda. In the present study roots and rhizospheric soil of 15 weeds species belonging to 12 families were collected from Carrot field of District Charsadda and was investigated for the sporulation and root infections types. From the recorded results the highest spore density was found in Melilotus indica having spore number 276 which is followed by Malva neglecta and Sonchus asper having spore number 244, 214 respectively. The lowest spore density was recorded in Pao annua having spore number 35. The maximum Glomus density was found in Melilotus indica having mean value $(83.67 \pm 1.65)$ whereas the maximum spore density was recorded for Acaulospora and Sclerocystis in the rhizospheric soil of Sonchus asper and Fumaria indica respectively. The root infection was also investigated which showed 20-85\% root infection. The highest root colonization was recorded in Parthenium hysterophorus $(39.67 \pm 11.02)$ whereas the lowest was found in Fumaria indica and Taraxacum officinale $(6.33 \pm 5.51),(8.00 \pm 4.00)$ respectively. It is not necessary that the plants having high spore density will have high root colonization the host growth stage of plant influences the diversity and population of Arbuscular mycorrhizal fungi (AMF). Our study revealed that the AMF spore density and root infection is closely related to the soil physicochemical characteristics.

Received | July 23, 2019; Accepted | April 30, 2020; Published | October 17, 2020

*Correspondence | Tabassum Yaseen, Department of Botany, Bacha Khan University, Charsadda, Khyber Pakhtunkhwa, Pakistan; Email: tabassumyaseen@bkuc.edu.pk

Citation | Yaseen, T., S. Ahmad, K.U. Rehman, F. Asad, A. Waheed, R. Gul, H. Gulab and N. Akhtar. 2020. Arbuscular mycorrhizal fungal spore density and root colonization in weeds of carrot field at Charsadda, Pakistan. Pakistan Journal of Agricultural Research, 33(4): 841-848.

DOI | http://dx.doi.org/10.17582/journal.pjar/2020/33.4.841.848

Keywords | AMF, Weeds, Carrot field, Glomus, Acaulospora, Sclerocystis
\end{abstract}

\section{Introduction}

1 he widespread symbiotic associations of of co-progressions actions between plants and fungi where both associates benefit from the exchange of nutrients (Sharma, 2003; Bonfant and Genre, 2008). It is reported that this type of association is most common and about $80 \%$ colonization was recorded from the species of higher plants (Koltai, 2010). In natural ecosystem Arbuscular mycorrhizal fungi (AMF) are regular components of the rhizospheric microflora which is necessary for maintainable plant soil system by establishing symbiotic associations with land plants and form mycorrhiza (Sharma et al., 2009). The fungus improves the capability of plants to absorb nutrients from the soil as well as to protect plants from diseases while the plant provides the 
carbon source to the fungus in soluble form (Auge, 2001; Entry et al., 2002; Wardle and Van der Putten, 2002; Gosling et al., 2006; Smith and Read, 2008; Sikes et al., 2009). The new secondary metabolites may also produce due the mycorrhizal associations of fungi with the plants (Venkateswarlu et al., 2008). It may also play a key role in vegetation restoration because of symbiosis with roots of plants; they can improve and stabilize structure of soil which can facilitate mineral absorption by the host plants and affect the structure of population and preserve the diversity of species (Bothe et al., 2010). AMF also recognized to benefit the plants to tolerate heavy metals present in the rhizospheric soil of the plants (Jamal et al., 2002; Turnau et al., 2005). It was reported that the root to shoot transport via phyto extractions and uptake of heavy metals were better in the mycorhizal colonized plants (Dodd, 2000). In addition, the AMF also reduce the heavy metals in the soil through phyto stabilizations (Khan, 2005). It may also provide other benefits to the host plants i.e. improve salinity and drought tolerance and disease resistance (Auge, 2001, 2004; Ruiz-Lozano, 2003). It is believed that AMF are ecologically important to numerous vascular plants and have the potential to alter the weed species ecology and can affect their growth without disturbing the growth of another major crop (Jordan et al., 2000). Whereas the AMF are not only beneficial but it may also cause negative effects on the growth of the host plants (Van der Heijden, 2002; Klironomos, 2003).

The phylum Glomeromycota of AM fungi are characterized by the production of intracellular absorptive structures Arbuscules and Vesicles are the utmost extensive of soil fungi tracked by ectomycorrhizal fungi (Koide and Mosse, 2004). In the natural ecosystem these are the regular components of rhizospheric microflora which form associations with plants and necessary for sustainable plant soil system. in the multispecies communities and natural plant populations the role of mycorrhiza is poorly understood (Sharma et al., 2009). Several work has been carried out in KP which include the work of Burni and Ilahi (2004), Zainab and Burni (2005), Sharief et al. (2005) and Nasrullah et al. (2010) about the distribution and occurrence of arbuscular mycorrhizal fungi but there is less information available therefore the present study was conducted to evaluate the occurrence and distributions of $\mathrm{AMF}$ in the rhizospheric soil of major weeds of District Charsadda.

\section{Materials and Methods}

Roots of fifteen weeds plants and their respective soil samples were collected from four different areas of Tehsil Charsadda during the session 20172018. Plant samples belong to different families, in which Asteraceae, Brassicaceae, Cannabaceae, Convolvulacea, Euphorbiaceae. Fabaceae, Fumariaceae, Malvaceae, Plantaginaceae, Poaceae, Ranunculaceae, and Zygophyllaceae species. The plants were carefully dug up along with there rhizospheric soil in triplicate and transported to laboratory in polythene bags. The plants roots were gentaly washed under tap water to remove soil particles, and the rhizosperic soil were shad dried. The roots were fixed in formaline acetic acid.

\section{Extraction of spores}

Rhizosheric soil samples of maize crop roots was collected at different stages. $100 \mathrm{gm}$ of the fine soil was taken and remove the debris and other larger particles and dissolved in the water and kept for about 24 hours' duration when the soil was completely settled down in the bottom of the beaker the water was passed through $2 \mathrm{~mm}$ sieve to remove the remaining residues. The cleaned water then passed from the three different sizes of sieves i.e. 140, 170 and $400 \mu \mathrm{m}$ one by one. The remaining residues above the sieves were collected by rubbing the filter paper on the sieves and studied under the compound microscope for the fungal species diversity and density. The spores were collected through needle and kept on the drop of canda balsam and the slides were made then the picture was capture for identification. For the identifications the manual of Hall and Fish (1979), Trappe (1982) were and density of spores were calculated.

\section{Roots infection observations}

For the root infection observations, the standard protocol of Giovannetti and Mosse (1980) and Kormanik (1982) was followed. The roots of the plants were washed with tap water to remove the formaline acetic acid molecules and then cut into pragments and heated for $10-15$ minutes in $10 \% \mathrm{KOH}$ solution. For the bleaching of the pigmented portions of the roots were then kept in alkaline $\mathrm{H}_{2} \mathrm{O}_{2}$ for about 1015 minutes. The bleached roots segments were then washed with tape water to remove the $\mathrm{H}_{2} \mathrm{O}_{2}$. After that the segments were treated with $1 \% \mathrm{HCL}$ for about 1-2 minutes to keep the acidic effect for proper staining. In $0.025 \%$ acidic fuchsine the roots segments 
were kept and heated for 2-3 minutes. Ten segments of about $1 \mathrm{~cm}$ length were randomly collected and kept under microscope for the morphological studies of amfa entophyte and microphotographs were taken. The percentage of infections was culculated by means of the mentioned formula.

$$
\% \text { age mycorrhizal infection }=\frac{\text { No.of infected segments }}{\text { Total No.of segments }} \times 100
$$

\section{Physiochemical analysis of soil}

The physicochemical parameters include the $\mathrm{pH}$, electric conductivity, soil texture, organic matter i.e. phosphorous, and potassium and nitrogen investigations. The $\mathrm{pH}$ and electric conductivity of the soil samples was recorded by the $\mathrm{pH}$ meter and EC bridge following the standard protocol of (Jackson, 1967; Black, 1965) respectively. The organic matter was determined by following the procedure of Neloson and Sommer (1982) through below mentioned formula

$$
\% \mathrm{O} . \mathrm{M}=\frac{\text { (meq. of } \mathrm{K} 2 \mathrm{Cr} 2 \mathrm{O} 2 \mathrm{meq} \text { of } \mathrm{FeSO} 4) \times 0.05 \times 100}{\text { Weight of soil }}
$$

\section{Results and Discussion}

\section{AMF spore density}

Roots along with rhizospheric soil of fifteen weed species collected from Carrot field of District Charsadda. The soil was investigated for the occurrence and distribution of mycorrhizal sporulation. Three Genus of spores have been isolated i.e. Glomus, Acaulospora and Sclerocystis. The highest spore density was found in the rhizospheric soil of the species of family Fabaceae with spore number 276, among all the other families. However, the lowest spore density was found for family Poaceae with spore number 35 (Figure 1 and Table 1). The statements were supported by Khakpour and Khara (2012) and (Surtiningsih et al., 2017) in this aspects that who also reported same results of sporulation from both the families respectively. Among all the spore types the Glomus genus was found to be dominant followed by Acaulospora and Sclerocystis (Figure 2). These findings are in agreement with those of (Chen et al., 2001; Pande and Tarafdar, 2004). The genus Glomus is predominantly distributed in the soil all over the world, the statement supported by (Minal and Anil, 2012). The genus Glomus and Acaulospora take short period of time for the production of small spores as compared to other genera which produce large spores. e.g. Gigaspora and Scutellospora (Sarkar et al., 2014). The widespread occurrence of Glomus may be attributed to their reproduction (Sporocarp formation), lower host preference and wide range of $\mathrm{pH}$ tolerance. It is known that soil factors such as $\mathrm{pH}$ restrict the distribution of some taxa (Abbott and Robson, 1991). In our study the soil $\mathrm{pH}$ is 6.1 (Figure 2) which is favourable for the growth of Glomus the statement is supported by Costa et al. (2013) who's reported the highest spore number of Glomus decipiens at $\mathrm{pH} 06.50$.

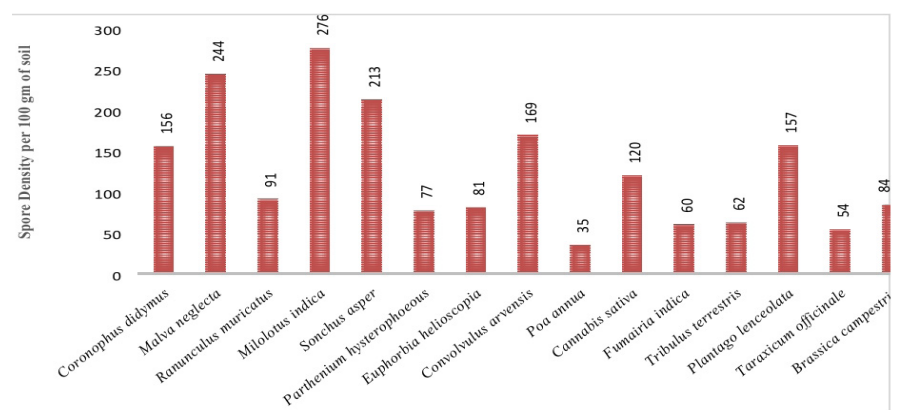

Figure 1: Total AMF spore density in selected weeds of carrot field.
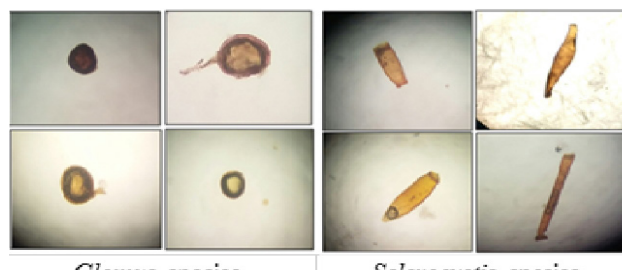

Sclerocystis species

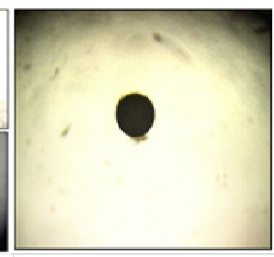

Acaulospora species Figure 2: Different types of spores isolated from weeds of carrot field.

The maximum Glomus density was recorded in $M$. indica (Fabaceae) with an average spore number of (83.67 \pm 1.65$)$, followed by $M$. neglecta and $S$. asper (Malvaceae and Asteraceae) with spore numbers $(59.33 \pm 1.62)$ and $(53.33 \pm 1.50)$ respectively. Our result agrees with the findings of (Dobo et al., 2016; Mergulhao et al., 2010) who's also studied genus Glomus in the above stated families. The minimum Glomus density was recorded in $P$. annua (Poaceae) with an average spore number of $(9.0 \pm 6.00)$, followed by $T$. officinale and B. campestris (Asteraceae) had spore number $(15.0 \pm 5.00)$ and $(18.33 \pm 2.18)$ respectively. The statement was in agreement to those of Hemavani and Thippeswamy, 2013 and Harikumar et al., 2014. In case of Acaulospora the maximum number of spores was recorded in $M$. neglecta and $S$. asper with average spore number $(21.67 \pm 1.66)$, and $(17.67 \pm 1.86)$. Our results agree with finding of (Bhale et al., 2011) who also reported same results of Acaulospora from the species of family Malvaceae and Asteraceae. The minimum number of Acaulospora was recorded in $C$. sativa and F. indica (Cannabaceae and Fumariaceae) 
Table 1: AMF spore density in selected weeds of carrot field of Tebsil Charsadda.

Plant Name

Family

Malva neglecta Wallr.

Ranunculus muricatus L.

Melilotus indica L.

Sonchus asper L.

Parthenium hysterophorus L.

Euphorbia helioscopia L.

Convolvulus arvensis $\mathrm{L}$.

Poa annua L.

Cannabis sativa L.

Fumaria indica L.

Tribulus terrestris L.

Plantago lenceolata L.

Taraxacum officinale Wigg.
Mean value of spores of Glomus $\boldsymbol{s p p}$.

$59.33 \pm 1.62$

Malvaceae

$21.33 \pm 1.50$

Ranunculaceae

$83.67 \pm 1.65$

Fabaceae

$53.33 \pm 1.50$

Asteraceae

$22.67 \pm 2.37$

Asteraceae

$23.00 \pm 2.14$

Euphorbiaceae

$49.67 \pm 3.84$

Convolvulaceae

$09.00 \pm 1.00$

Poaceae

$35.67 \pm 2.29$

Cannabaceae

$15.00 \pm 1.11$

Fumariaceae

$17.67 \pm 7.51$

Plantaginaceae

$45.67 \pm 4.61$

Asteraceae

$15.00 \pm 5.00$
AMF Spore Density

Mean value of spores Mean value of spores of Acaulospora spp.

$21.67 \pm 1.66$

$09.00 \pm 3.00$

$0.33 \pm 0.58$

$07.00 \pm 1.36$

$00.00 \pm 0.00$

$01.33 \pm 0.58$

$17.67 \pm 1.86$

$00.00 \pm 0.00$

$02.67 \pm 2.08$

$00.33 \pm 0.58$

$03.33 \pm 3.21$

$00.67 \pm 0.58$

$04.67 \pm 2.08$

$02.00 \pm 2.65$

$02.33 \pm 2.08$

$00.33 \pm 0.58$

$01.67 \pm 1.53$

$02.67 \pm 4.62$

$01.67 \pm 1.53$

$03.33 \pm 4.16$

$02.00 \pm 1.00$

$01.00 \pm 1.00$

$03.67 \pm 4.73$

$03.00 \pm 3.61$

$02.00 \pm 1.73$

$01.00 \pm 1.00$

Each value is the grand mean \pm Standard deviation of five replicates.

with average spore number of $1.67 \pm 1.53$ respectively. The statement was supported by Agwa and A1Sodany, 2003 and Birhane et al., 2017. Among all the spores the Sclerocystis was found to be formed small community, the highest number of Sclerocystis was recorded in $F$. indica, $P$. lanceolata and $C$. sativa with average spore number of $3.33 \pm 4.16,3.00 \pm 3.61$ and $2.67 \pm 4.62$ respectively, whereas in the rhizosperic soil of $R$. muricatus and $S$. asper no Sclerocystis was found (Datta and Kulkarni, 2012).

\section{Root colonization}

All the weed species were also investigated for the root infection (Figure 4). All the species showed Mycorrhizal infection in their roots except (Brassicaceae) but the degree of colonization varied among plant species. Typical fungal structures were found, i.e. Arbuscules, Vesicles, External Hyphae and Internal Hyphae. The root infection was recorded from the minimum $20 \%$ to the maximum $85 \%$. The highest root colonization was recorded in $P$. bysterophorus with mean percentage $39.67 \pm 11.02$ which is followed by $R$. muricatus $34.00 \pm 15.39$. Our result agrees with that of Hemavani and Thippeswamy, 2013; Rodriguez-Rodriguez et al., 2013; Wang and Jiang, 2015 who also reported root infection from same families. The moderate colonization was found in $S$. asper $(23.67 \pm 10.60)$ and $P$. annua $(20.00 \pm 16.37)$ (Figure 3). The statement supported by Khakpour and Khara, 2012 in this aspects that who's recorded $62.7 \%$ colonization in Poaceae. The lowest percentage of colonization was recorded in $F$. indica $(6.33 \pm 5.51)$ followed by $T$. officinale $(8.00 \pm 4.00)$. Our results agree with the findings of Shi et al., 2006 who recorded $17 \%$ colonization in Asteraceae. The highest vesicular infection was recorded in $P$. bysterophorus whereas the highest arbuscular infection was recorded in $R$. muricatus and $S$. asper the present findings was supported by the results of Birhane et al., 2017 who's reported highest vesicular infection in family Rosaceae and Milaceae and highest arbuscular infection in Boraginaceae (Figures 3 and 4). In the present study the two species $C$. didymus and $B$. campestris of family Brassicaceae showed no AMF colonization, the statement is supported by (Harikumar et al., 2014).

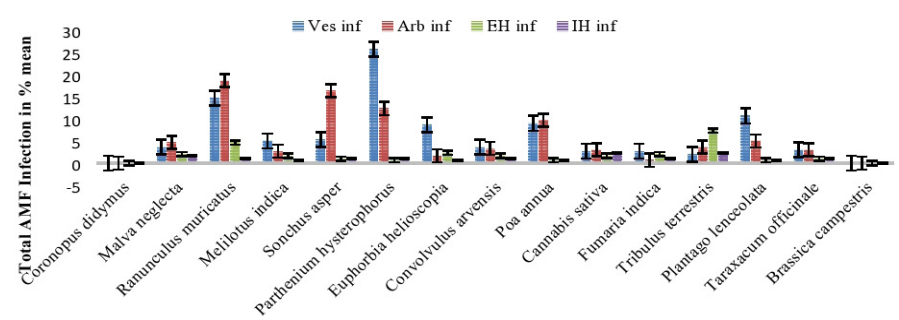

Figure 3: Mean percentage of highest root colonization in selected weeds of carrot field. Ves (vesicles), Arb (arbuscules), EH (external byphae), IH (internal byphae).
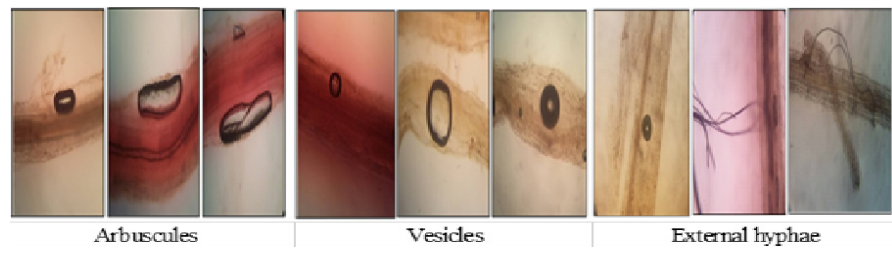

Figure 4: Different types of mycorrbizal roots infection. 
The soil was also used to evaluate its physicochemical parameters including the $\mathrm{pH}$, electric conductivity, soil texture, organic matter i.e. phosphorous, potassium and nitrogen investigations. The results of the physicochemical parameters revealed that the soil was loamy in nature. The $\mathrm{pH}$ and $\mathrm{EC}$ was recoded as $6.14 \pm 0.65$ and $0.14 \pm 0.12$. The organic matter for the soil was found to be $1.27 \pm 0.20$. The study also reported that the soil contained mostly the element potassium which was $101.73 \pm 22.12$ followed phosphorous $(3.01 \pm 2.10)$ (Table 2). The edaphic characteristic were in agreement to those of Lekberg et al. (2007) and Oehl et al. (2004) in this aspects that who's also reported the type of soil, soil depth, soil $\mathrm{pH}$ and soil fertility.

Table 2: Shows mean values of different chemical constituents of soil.

$\begin{array}{ll}\text { Parameters } & \text { Values } \\ \mathrm{pH} & 06.14 \pm 0.65 \\ \mathrm{EC} \mathrm{ds} / \mathrm{m} & 00.14 \pm 0.12 \\ \mathrm{OM} \% & 01.27 \pm 0.20 \\ \mathrm{~N} \% & 00.17 \pm 0.06 \\ \mathrm{P} \mathrm{mg} / \mathrm{kg} & 03.01 \pm 2.10 \\ \mathrm{~K} \mathrm{mg} / \mathrm{kg} & 101.73 \pm 22.12 \\ \text { Textural class } & \text { Loamy }\end{array}$

P: available Phosphorous; K: available Potassium; N: available Nitrogen; OM: organic matter; EC: electrical conductivity; means of fifteen replicates \pm standard deviation.

\section{Conclusions and Recommendations}

The results of the study concluded that there is a high incidence of AMF associations in the weed plants of studied area. All the weeds of selected locations were colonized except (Brassicaceae) by AMF. This study reports three genus of Glomus, Sclerocystis and Acaulospora from the studied sites on the basis of spore's identification. The abundance of Glomus genus is due to Phosphorous $(\mathrm{P})$ deficiency in the area, also the area has normal $\mathrm{pH}$ whereas the genus Acaulospora prefers to slightly acidic conditions. The vesicles, Arbuscules, External hyphae and Internal hyphae was also reported. All the findings provide the way to the agriculture sector that where is less microflora present their will be deficiency of some minerals as well as efficiency may also be produce due mycorrhizal associations. Whereas the effect on plant communities either in positive direction or it may be in negative.

\section{Novelty Statement}

The study is novel for carrot growers as it guides about weed control in carrot fields. The finding states that Arbuscular mycorrbizal fungi (AMF) controls weeds and enhances growth of carrot.

\section{Author's Contribution}

Tabassum Yaseen and Shehzad Ahmad designed experiment, performed and wrote paper. Fayaz Asad paper revised. Khushnood ur Rahman, Abdul Waheed and Rani Gul in data analysis. Hussain Gulab and Naveed Akhtar technical guidance

Conflict of interest

The authors have declared no conflict of interest.

\section{References}

Abbott, L.K. and A.D. Robson. 1991. Factors influencing the occurrence of vesiculararbuscularmycorrhizas.Agric.Ecosyst.Environ., 35: 121-150. https://doi.org/10.1016/01678809(91)90048-3

Agwa,H.E. and Y.M.A1-Sodany. 2003. Arbuscularmycorrhizal fungi (Glomales) in AMF in wheat and Maize crops of Malakand Division of North west Frontier Province. Pak. J. Bot., 42(2): 1301-1312.

Auge, R.M., 2001. Water relations, drought and vesicular-arbuscular mycorrhiza symbiosis. Mycorrhiza. 11: 3-42. https://doi.org/10.1007/ s005720100097

Auge, R.M., 2004. Arbuscular mycorrhizae and soil / plant water relations. Can. J. Soil Sci., 84: 373-381. https://doi.org/10.4141/S04-002

Bhale, U.N., V.S. Sawant and P.P. Sarwade. 2011. Arbuscular Mycorrhizas of some plants growing in Marathwada Region of Maharashtra. Kavaka., 39: 33-36.

Birhane, E., K.M. Gebremedihin, T. Tadesse, M. Hailemariam and N. Solomon.2017. Exclosures restored the density and root colonization of arbuscular mycorrhizal fungi in Tigray, Northern Ethiopia. Ecol. Proces., 6: 33. https:// doi.org/10.1186/s13717-017-0101-9

Black, C.A., 1965. Methods of soil analysis. Part I, American Society of Agronomy. Madison, Wisconsin, USA. pp. 1572. https://doi. org/10.2134/agronmonogr9.1 
Bonfante, P. and A. Genre. 2008. Plants and arbuscular mycorrhizal fungi: an evolutionarydevelopmental perspective. Trends Plant Sci., 13(9): 492-498. https://doi.org/10.1016/j. tplants.2008.07.001

Bothe, H., K. Turnau and M. Regvar. 2010. The potential role of Arbuscular mycorrhizal fungi in protecting endangered plants and habitats. Mycorrhiza. 20(7): 445-457. https://doi. org/10.1007/s00572-010-0332-4

Burni, T. and I. Illahi. 2004. Quantification and correlation of VAM spores with the soil characteristics of Wheat fields of NWFP. Pak. J. Plant Sci., 10: 139-144.

Chen, X., Z. Fang and J. Tang. 2001. Investigation on host plants of Vesicular-Arbuscular Mycorrhiza fungi (VAMF) within weed community in agricultural slope land in red soil area, southeastern China. Biodiver. Sci., 9: 122128.

Datta, P. and M. Kulkarni. 2012. Arbuscular Mycorrhizal Fungal Diversity in Sugarcane Rhizosphere in Relation with Soil Properties. Not. Sci. Biol., 4(1): 66-74. https://doi. org $/ 10.15835 / \mathrm{nsb} 416567$

Dobo, B., F. Asefa and Z. Asfaw. 2016. Diversity and Abundance of Arbuscular Mycorrhizal Fungi Under Different Plant and Soil Properties in Sidama, Southern Ethiopia. Adv. Biosci. Bioeng., 4(3): 16-24. https://doi. org/10.11648/j.abb.20160403.11

Dodd,J.C., 2000. The role of arbuscular mycorrhizal fungi in agro- and natural ecosystems, Outlook. Agric., 29: 55-62. https://doi. org/10.5367/000000000101293059

Entry, J.A., P.T. Rygiewicz, L.S. Watrud and P.K. Donnelly. 2002. Influence of adverse soil conditions on the formation and function of arbuscular mycorrhizas. Adv. Environ. Res., 7: 123-138. https://doi.org/10.1016/S10930191(01)00109-5

Glovannetti, M, and B. Mosse. 1980. An evaluation of techniques for measuring vesicular arbuscular mycorrhizal infection in roots. New Phytol. 84(3): 489-500. https://doi. org/10.1111/j.1469-8137.1980.tb04556.x

Gosling, P., A. Hodge, G. Goodlass, G.D. Bending. 2006. Arbuscular mycorrhizal fungi and organic farming. Agric. Ecosyst. Environ., 113: 17-35. https://doi.org/10.1016/j.agee.2005.09.009

Hall, I.R. and B.J. Fish. 1979. A key to the
Endogonaceae. Trans. Br. Mycol. Soc., pp.

73-261. https://doi.org/10.1016/S00071536(79)80110-2

Harikumar, V.S., J. Blaszkowski, G. Medhanie, M.K. Kanagaraj and D.V. Samuel. 2014. Arbuscular Mycorrhizal Fungi Colonizing the plant Communities in Eritrea, Northeast Africa. Appl. Ecol. Environ. Res., 13(1): 193-203. https://doi.org/10.15666/aeer/1301_193203

Hemavani, C. and B. Thippeswamy. 2013. Arbuscular mycorrhizal fungi associated with some plants of Asteraceae in Bhadra wildlife sanctuary. Int. J. Plant, Anim. Environ. Sci., 2(3): 106-110.

Jackson, M.L., 1967. Soil chemical analysis. Prentice-Hall of India Pvt. Ltd., New Delhi. pp. 498.

Jamal,A., N.Ayub,M.Usman and A.G.Khan.2002. Arbuscular mycorrhizal fungi enhance zinc and nickel uptake from contaminated soil by soybean and lentil.Int.J. Phytorem., 4: 205-221. https://doi.org/10.1080/15226510208500083

Jordan, N.R., J. Zhang and S. Huerd. 2000. Arbuscular mycorrhizal fungi: potential roles in weed management. Weed Res., 40: 397-410. https://doi.org/10.1046/j.13653180.2000.00207.x

Khakpour, O., and J. Khara.2012. Spore density and root colonization by Arbuscular Mycorrhizal fungi in some species in the northwest of Iran. Int. Res. J. App. B. Sci., 3(5): 977-982.

Khan, A.G., 2005. Role of soil microbes in the rhizospheres of plants growing on trace lement contaminated soils in phytoremediation. J. Trace Elem. Med. Biol., 18: 355-364. https:// doi.org/10.1016/j.jtemb.2005.02.006

Klironomos, J.N., 2003. Variation in plant response to native and exotic arbuscular Mycorrhizal fungi. Ecology. 84: 2292-2301. https://doi. org/10.1890/02-0413

Koide,R.T.and B.Mosse.2004.A history of research on arbuscular mycorrhizal fungi. Mycorrhiza. 14: 145-163. https://doi.org/10.1007/s00572004-0307-4

Koltai, H., 2010. Mycorrhiza in floriculture: difficulties and opportunities. Symbiosis. 52: 55-63. https://doi.org/10.1007/s13199-0100090-2

Kormanik, P.P., and A.C. McGRAW. 1982. Quantification of vesicular arbuscular m corrhizae in plant roots. In Methods and 
Principles of $M \sim$ corrhizal Research (ed. N. C. Schenck). St.Paul: American Phytopathological Society. pp. 37-45.

Lekberg, Y., R.T. Koide, J.R. Rohr, L. AldrichWolfe and J.B. Morton. 2007. Role of lement contaminated soils in phytoremediation. J. Trace Elem. Med. Biol., 18: 355-364.

Mergulhao, A.C.E., H.A. Burity, B.T. Goto and L.C. Maia. 2010. Diversity of Arbuscular Mycorrhizal fungi in a gypsum mining impacted semiarid area. Acta bot. Bras., 24(4): 1052-1061. https://doi.org/10.1590/S010233062010000400020

Minal,T. and V.Anil.2012. Mycorrhizae at polluted site of western Rajasthan. Int. J. Plant Anim. Environ. Sci., 2: 325-487.

Nasrullah, M. Sharief, K. Robina and T. Burni. 2010. Occurrence and distribution of niche restrictions and dispersal in the composition in arbuscular Mycorrhizal fungal communities. J. Ecol., 95: 95-105. https://doi.org/10.1111/ j.1365-2745.2006.01193.x

Nelson, D.W. and L.E. Sommers. 1982. Total carbon, organic carbon and organic matter. In: A.L. Page et al. (ed.) Methods of soil analysis: Part 2.pp. 539-579.

Oehl, F., E. Sieverding, K. Ineichen, E-A. Ris, T. Boller and A. Wiemken. 2004. Community structureof arbuscular mycorrhizal fungi at different soil depths in extensively and intensively managed agro-ecosystems. New Phytologist. 165: 273-283. https://doi. org/10.1111/j.1469-8137.2004.01235.x

Oehl, F., E. Sieverding, P. Ma"der, D. Dubois and K. Ineichen. 2004. Impact of longterm conventional and organic farming on the diversity of Arbuscular mycorrhizal fungi. Oecologia. 138: 574-583. https://doi. org/10.1007/s00442-003-1458-2

Pande, M. and J.C. Tarafdar. 2004. Arbuscular mycorrhizal fungal diversity in Neem-plants growing in Marathwada Region of Maharashtra. Kavaka. 39: 33-36.

Rodriguez-Rodriguez, R.M., P. Herrera and E. Furrazola. 2013. Arbuscular mycorrhizal colonization in Asteraceae from white sand savannas, in Pinar del Río, Cuba.Biota. Neotrop., 13(3): 136-140. https://doi.org/10.1590/ S1676-06032013000300017

Ruiz-Lozano, J.M., 2003. Arbuscular mycorrhizal symbiosis and alleviation of osmotic stress. New perspectives for molecular studies. Mycorrhiza. 13: 309-317. https://doi.org/10.1007/s00572003-0237-6

Sarkar, U., B.K. Choudhary and B.K. Sharma. 2014. Vascular Arbuscular Mycorrhizal (VAM) Spore Diversity and Density Across the Soil of Degraded Forest and Rubber Plantation in Tripura, India. Am. -Eurasian J. Agric. Environ. Sci., 14 (10): 1080-1088.

Sharief, M., T. Burni and Saima. 2005. Arbuscular mycorrhizal incidence and infectivity in wheat and Maize crops of Bannu and D.I. Khan areas, Pakistan. Pak. J. Plant Sci., 11(1): 67-77.

Sharma, D., R. Kapoor and A.R. Bhaytnagar. 2009. Differential growth response of Curculigo orchoides to native AMF communities varying in number and fungal components. Eur. J. Soil Biol.,45(4):328-333.https://doi.org/10.1016/j. ejsobi.2009.04.005

Sharma, O.P., 2003. Textbook of Fungi. TaTa McGraw-Hill Publishing Company Limited. India. pp. 312.

Shi, Z.Y., G. Feng, P. Christie and X.L. Li. 2006. Arbuscular mycorrhizal status of spring ephemerals in the desert ecosystem of Junggar Basin, China. Mycorrhiza. 16:269-275.https:// doi.org/10.1007/s00572-006-0041-1

Sikes, B.A., K. Kottenie and J.N. Klironomos. 2009. Plant and fungal identity determines pathogen protection of plant roots by arbuscular mycorrhizas. J. Ecol., 97: 1274-1280. https:// doi.org/10.1111/j.1365-2745.2009.01557.x

Smith, S.E. and D.J. Read. 2008. Mycorrhizal symbiosis, $3^{\text {rd }}$ edn. Academic Press, San Diego.

Surtiningsih, T., R. Hapsari, N.A. Elhany and H. Purnobasuki. 2017. Biodiversity of arbuscular mycorrhizal from rhizosfer soil contaminated petroleum hydrocarbon in Bojonegoro East Java. J. Appl. Environ. Biol. Sci., 7(7): 19-25.

Trappe, J.M., 1982. Synoptic keys to the genera and species of zygomycetous mycorrhizal fungi. Phytopathol. 72 (8): 1102-1107.

Turnau, K., A.Jurkiewicz, G. Lingua,J.M. Barea and V. Gianinazzi-Pearson. 2005. Role of arbuscular mycorrhiza and associated microorganisms in phytoremediation of heavy metal polluted sites. In: Trace Elements in the Environment, Prasad, M.N.V., Sajwan, K.S. and Naidu, R. (eds), CRC Press, Florida, pp. 235-252. https://doi. org/10.1201/9781420032048.ch13

Van der Heijden, M.G.A., 2002. Arbuscular 
mycorrhizal fungi as a determinant of plant Venkateswarlu, B., M. Pirat, N. Kishore and A. Rasul. 2008. Mycorrhizal inoculation in neem (Azadirachta indica) enhances azadirachtin content in seed kernals. World J. Microbiol. Biotechnol., 24: 1243-1247. https://doi. org/10.1007/s11274-007-9593-2

Venkateswarlu, B., S. Desai and Y.G. Prasad. 2008. Agriculturally important microorganisms for stressed ecosystems: Challenges in technology development and application. In: Khachatourians GG, Arora DK, Rajendran TP, Srivastava AK (eds) Agriculturally important Microorganisms. Academic World, Bhopal, pp. 225-246.

Wang, M. and P. Jiang. 2015. Colonization and diversity of AM fungi by morphological analysis on medicinal plants in Southeast China. Sci. World J., pp. 1-7. https://doi. org/10.1155/2015/753842

Wardle, D.A. and W.H. Van der Putten. 2002. Biodiversity, ecosystem functioning and aboveground- below-ground linkages. In: M. Loreau, S. Naeem and P. Inchausti (eds.), Biodiversity and Ecosystem Functioning: Synthesis and perspectives. Acad. Press, New York. pp. 155168.

Zainab, S.B. and T. Burni. 2005. Vesicular Arbuscular mycorrhizal studies in weeds of wheat fields of Peshawar, Pakistan. Pak. J. Plant Sci., 11: 93-101. 